\title{
Validasi Metode Analisis Kadar Kalsium pada Susu Segar secara Titrasi Kompleksometri
}

\author{
Validation of Method of Calcium Analysis in Fresh Milk using Complexometric Titration
}

\author{
Moh. Taufik*, Seveline, Emilia Ratih Saputri \\ Program Studi IImu dan Teknologi Pangan, Fakultas Bioindustri, Universitas Trilogi, Jl. TMP, Kalibata No. 1, Jakarta \\ Selatan 12760, Indonesia \\ *Email: filik_fik36@yahoo.co.id
}

Tanggal submisi: 30 Mei 2017; Tanggal penerimaan: 7 Mei 2018

\begin{abstract}
ABSTRAK
Analisis kadar kalsium pada susu segar umumnya menggunakan Atomic Absorption Spectroscopy (AAS) yang relatif mahal. Salah satu metode alternatif yang dapat digunakan adalah titrasi kompleksometri. Sampai sekarang, data validasi terhadap metode tersebut pada sampel susu segar belum tersedia. Tujuan penelitian ini adalah memvalidasi metode analisis kadar kalsium pada susu segar secara titrasi kompleksometri. Hasil penelitian menunjukkan uji linearitas dengan menggunakan larutan standar kalsium pada rentang 4-24 mg/100 mL mempunyai nilai $R^{2}$ sebesar 0,9983 , sedangkan nilai batas deteksi dan batas kuantifikasi berturut-turut adalah 0,47 mg/100 mL dan 1,57 mg/100 $\mathrm{mL}$. Nilai akurasi (recovery) sebesar $99,29 \%$ pada konsentrasi spiking $60 \mathrm{mg} / 100 \mathrm{~mL}$ sampel. Hasil penelitian atau metode uji yang divalidasi menunjukkan nilai keterulangan dan reprodusibilitas intralab yang baik dengan nilai CV analisis berturut-turut $0,98 \%$ dan 2,59\%. Hasil uji ketangguhan menunjukkan metode ini bersifat tangguh ( $r u g g e d$ ) terhadap variasi volume sampel dan konsentrasi asam etilenadiaminatetraasetat (EDTA) yang digunakan. Berdasarkan hasil penelitian tersebut, metode titrasi kompleksometri dapat digunakan untuk menentukan kadar kalsium pada susu segar.
\end{abstract}

Kata kunci: Analisis kalsium; titrasi kompleksometri; susu segar; validasi metode

\begin{abstract}
Analysis of calcium content in fresh milk generally uses Atomic Absorption Spectroscopy (AAS). Alternatively, it could be analyzed using complexometric titration. The study aimed to validate the method of calcium content analysis in fresh milk by complexometric titration. The results showed that the linearity test using calcium standard solution at a working range of $4-24 \mathrm{mg} / 100 \mathrm{~mL}$ had $\mathrm{R}^{2}$ of 0.9983 , while the limit of detection and limit of quantification were 0.47 $\mathrm{mg} / 100 \mathrm{~mL}$ and $1.57 \mathrm{mg} / 100 \mathrm{~mL}$, respectively. The accuracy by spiking method at the spiking concentration of 60 $\mathrm{mg} / 100 \mathrm{~mL}$ sample was $99.29 \%$. The repeatability and intra-lab reproducibility showed acceptable precision with CV value of $0.98 \%$ and $2.59 \%$, respectively. The results of ruggedness test showed that this method was rugged to the variation of sample volume and ethylenediaminetetraacetic acid (EDTA) concentration. This study proved that complexometric titration can be used to determine calcium content in fresh milk.
\end{abstract}

Keywords: Calcium analysis; complexometric titration; fresh milk; method validation

\section{PENDAHULUAN}

Susu merupakan bahan makanan yang mempunyai nilai gizi yang tinggi. Salah satu zat gizi yang terdapat pada susu adalah mineral. Menurut Barłowska dkk. (2011), susu mengandung beberapa mineral seperti kalsium, fosfor, natrium, kalium, klorida, iodin, magnesium dan mineral lain dalam jumlah kecil. Dua mineral utama yang terdapat pada susu adalah kalsium dan fosfor (Al-Wabel, 2008). Kalsium merupakan mineral esensial yang dibutuhkan untuk berbagai fungsi tubuh (Gobinathan dkk., 2009; Beto, 2015), seperti pembentukan tulang, pembekuan darah, katalisator reaksi biologis dan mengatur kontraksi otot. Kadar kalsium pada susu segar hasil penelitian Park dkk. (2007) adalah $122 \mathrm{mg} / 100 \mathrm{~g}$.

Ada beberapa metode yang dapat digunakan untuk analisis kadar kalsium, yaitu AAS (atomic absorption spectrometry) (Sowmya dkk., 2015), titrimetri (Basak 
dan Kundu, 2013; Kapadnis, 2015), ICP-OES (inductively couple plasma optical emission spectrometry (Kumaravel dan Alagusundaram, 2014) dan ICP-MS (inductively couple plasma mass spectrometry) (Poirier dkk., 2016). Menurut Petrovich dkk. (2007), metode yang umum untuk analisis kadar kalsium adalah AAS dan titirimetri. AAS dan titrimetri banyak digunakan dibandingkan ICPOES dan ICP-MS karena lebih simpel, akurat dan presisi yang tinggi (Petrovich dkk., 2007). Penentuan logam dengan menggunakan AAS memerlukan biaya yang lebih mahal dan membutuhkan peralatan khusus (Cai dkk., 2009), sehingga metode titrimeti dapat digunakan sebagai metode alternatif yang lebih murah. Salah satu metode titrimetri adalah kompleksometri.

Menurut Day dan Underwood (2006), titrasi kompleksometri merupakan salah satu jenis titrasi yang didasarkan pada reaksi pembentukan senyawa kompleks antara ion logam target dengan zat pembentuk kompleks. Zat pembentuk kompleks yang umum digunakan adalah asam etilenadiaminatetraasetat (EDTA) yang akan membentuk kompleks kuat dengan perbandingan 1:1 dengan logam (Ward dan Carpenter, 2010). pH larutan dalam titrasi kompleksometri harus dikontrol (Nielsen, 2010), karena akan menentukan selektivitas pembentukan kompleks antara EDTA dengan logam target. BSN (2004) merekomendasikan nilai pH larutan 12-13 untuk analisis kadar kalsium. Beberapa penelitian menggunakan kisaran $\mathrm{pH}$ tersebut, yaitu Basak dan Kundu (2013) yang menggunakan pH larutan 12 untuk menganalisis kadar kalsium pada sampel bahan baku keramik, sedangkan Rusdi dkk. (2013) juga menggunakan $\mathrm{pH}$ larutan 12 untuk menentukan kadar kalsium pada batu kapur.

Di Indonesia, titrasi kompleksometri berdasarkan pada SNI 06-6989.13-2004. SNI tersebut merupakan prosedur analisis kadar kalsium untuk air dan air limbah. Beberapa penelitian menggunakan metode titrasi kompleksometri untuk menentukan kadar kalsium pada beberapa sampel. Miefthawati dkk. (2013), menganalisis kadar kalsium pada beberapa sampel ikan kembung menggunakan metode titrasi kompleksometri dan mendapatkan kadar kalsium sebesar 0,18-0,36\%. Setyawan dkk. (2017), menentukan kadar kalsium pada bayam hijau rebus dan segar dengan metode titrasi kompleksometri dan mendapatkan kadar kalsium sebesar $0,07 \%$ dan $0,13 \%$. Analisis kadar kalsium pada susu segar dengan menggunakan metode titrasi kompleksometri belum tersedia data validasinya. Menurut Kazusaki dkk. (2012), validasi merupakan suatu proses untuk membuktikan bahwa suatu metode dapat digunakan berdasarkan beberapa parameter tertentu. Menurut Riyanto (2014), validasi dapat membantu memberikan jaminan bahwa hasil analisis dapat dipercaya. Pada penelitian ini dilakukan validasi terhadap metode analisis kadar kalsium pada susu segar secara titrasi kompleksometri. Parameter validasi yang dijadikan acuan adalah batas deteksi, batas kuantifikasi, linearitas, akurasi, keterulangan, reprodusibilitas intralab, ketangguhan metode, dan ketidakpastian.

\section{METODE PENELITIAN}

\section{Alat dan Bahan}

Alat yang digunakan pada penelitian ini adalah timbangan analitik Kern ABJ-NM/ABSN (Kern \& Sohn $\mathrm{GmbH}$, Balingen, Jerman), indikator universal $\mathrm{pH} \mathrm{0-14}$ MColorpHast ${ }^{\mathrm{TM}}$ (Merck KGaA, Darmstadt, Jerman), buret, statif, erlenmeyer, labu ukur dan pipet volumetrik. Sampel yang digunakan adalah susu segar (fresh milk) yang diperoleh dari peternakan sapi (Jakarta, Indonesia).

Bahan kimia yang digunakan adalah $\mathrm{Na}_{2} \mathrm{EDTA} \cdot 2 \mathrm{H}_{2} \mathrm{O}$, $\mathrm{ZnSO}_{4} \cdot 7 \mathrm{H}_{2} \mathrm{O}$, indikator eriochrome black $\mathrm{T}, \mathrm{NH}_{4} \mathrm{OH}$, $\mathrm{NH}_{4} \mathrm{OH}, \mathrm{CaCl}_{2} \cdot 2 \mathrm{H}_{2} \mathrm{O}$, indikator muraksid, $\mathrm{NaOH}$ dan $\mathrm{NaCl}$. Bahan kimia tersebut diperoleh dari Merck (Darmstadt, Jerman). Bahan kimia lain yang digunakan adalah aquabides yang diperoleh dari Polylab Sinar Klaten (Jakarta, Indonesia).

\section{Batas Deteksi dan Batas Kuantifikasi}

Batas deteksi (limit of detection) dan batas kuantifikasi (limit of quantification) ditentukan dengan menggunakan larutan standar kalsium pada konsentrasi rendah, yaitu $1 \mathrm{mg} / 100 \mathrm{~mL}$. Sebanyak $100 \mathrm{~mL}$ dari larutan tersebut dititrasi dengan menggunakan larutan $\mathrm{Na}_{2}$ EDTA 0,050 M yang sudah dibakukan dan dihitung konsentrasi kalsium dan standar deviasinya (SD). Jumlah ulangan yang digunakan adalah tujuh kali ulangan. Nilai batas deteksi adalah tiga kali nilai SD, sedangkan batas kuantifikasi adalah 3,3 kali dari nilai batas deteksi (Squadrone dkk., 2010).

\section{Linearitas}

Linearitas (linearity) ditentukan dengan menggunakan larutan standar kalsium pada enam konsentrasi berbeda, yaitu $4 \mathrm{mg} / 100 \mathrm{~mL}, 6 \mathrm{mg} / 100 \mathrm{~mL}$, $8 \mathrm{mg} / 100 \mathrm{~mL}, 10 \mathrm{mg} / 100 \mathrm{~mL}, 12 \mathrm{mg} / 100 \mathrm{~mL}$, dan 24 $\mathrm{mg} / 100 \mathrm{~mL}$. Sebanyak $100 \mathrm{~mL}$ dari larutan tersebut dititrasi dengan menggunakan larutan Na2EDTA 0,050 M yang sudah dibakukan. Jumlah ulangan yang digunakan adalah tiga kali ulangan. Linieritas diukur dengan nilai $\mathrm{R}^{2}$ dari kurva hubungan antara volume larutan $\mathrm{Na}_{2}$ EDTA (sebagai sumbu y) yang digunakan untuk titrasi dengan konsentrasi larutan standar kalsium (mg/100 mL) (sebagai sumbu $\mathrm{x}$ ). Linieritas yang baik adalah $\mathrm{R}^{2}$ lebih dari 0,99 (AOAC, 2012).

\section{Akurasi dan Keterulangan}

Akurasi (accuracy) ditentukan dengan melakukan uji recovery dengan jumlah sampel awal $4 \mathrm{~mL}$ susu segar. Uji ini dilakukan dengan menggunakan sampel tanpa spike dan sampel dengan spike kalsium. Konsentrasi spiking yang digunakan adalah $60 \mathrm{mg} / 100 \mathrm{~mL}$ sampel. Jumlah ulangan yang digunakan adalah tiga kali ulangan untuk sampel tanpa spike dan enam kali ulangan untuk sampel dengan spike. Akurasi dihitung sebagai nilai recovery, sedangkan keterulangan (repeatability) ditentukan dengan membandingkan koefisien varian 
(Coefficient of Variation/CV) hasil analisis dengan CV yang dipersyaratkan oleh AOAC (2012). Penentuan nilai recovery dan $\mathrm{CV}$ analisis mengikuti pada Persamaan 1 dan 2.

Recovery $(\%)=$

$\frac{\text { Kadar kalsium pada sampel dengan spike -Kadar kalsium pada sampel tanpa spike }}{\text { Konsentrasi spiking kalsium }} \times 1$

CV analisis $(\%)=\frac{S D}{\bar{x}} \times 100 \%$

Keterangan:

$\mathrm{CV}$ analisis $=$ Koefisien varian hasil analisis (\%)

$\mathrm{SD}=\quad=$ Standar deviasi kadar kalsium $(\mathrm{mg} / 100 \mathrm{~mL})$

$\bar{x} \quad=$ Rata-rata kadar kalsium $(\mathrm{mg} / 100 \mathrm{~mL})$

\section{Reprodusibilitas Intralab}

Uji reprodusibilitas intralab (intra-laboratory reproducibility) ditentukan dengan menganalisis sampel pada tiga hari berbeda. Jumlah ulangan yang digunakan adalah tiga kali ulangan untuk setiap kali pengukuran. Sebanyak $4 \mathrm{~mL}$ sampel dianalisis kadar kalsiumnya. Metode analisis kadar kalsium mempunyai reprodusibilitas yang baik apabila nilai CV analisis hasil pengujian tiga hari lebih kecil dari nilai CV yang dipersyaratkan oleh AOAC (2012).

\section{Ketangguhan}

Ketangguhan metode (ruggedness) diuji dengan memvariasikan volume sampel awal dan konsentrasi larutan $\mathrm{Na}_{2} \mathrm{EDTA}$ yang digunakan pada saat analisis. Variasi jumlah sampel awal yang digunakan adalah $3 \mathrm{~mL}$, $4 \mathrm{~mL}$ dan $5 \mathrm{~mL}$, sedangkan variasi konsentrasi larutan $\mathrm{Na}_{2}$ EDTA yang digunakan adalah 0,050 M dan 0,025 M. Sampel setelah perlakuan dianalisis kadar kalsiumnya. Jumlah ulangan yang digunakan adalah tiga kali ulangan. Hasil analisis kadar kalsium dihitung, kemudian diuji secara statistik (ANOVA) untuk mengetahui apakah hasil analisis kadar kalsium berbeda nyata atau tidak. Metode analisis kadar kalsium bersifat tangguh apabila hasil uji ANOVA tidak berbeda nyata.

\section{Ketidakpastian}

Dua jenis ketidakpastian (uncertainty) yang ditentukan pada penelitian ini adalah ketidakpastian keterulangan $\left(\mathrm{U}_{\mathrm{r}}\right)$ dan ketidakpastian reprodusibilitas $\left(U_{R}\right)$. Penentuan $U_{r}$ dan $U_{R}$ berdasarkan pada Česnik dan Gregorčič (2006) seperti Persamaan 3.

$\mathrm{U}_{\mathrm{r}}=\mathrm{t}_{95: 9} \times \mathrm{SD}_{\mathrm{r}} ; \mathrm{UR}_{\mathrm{R}}=\mathrm{t}_{95: 9} \times \mathrm{SD}_{\mathrm{R}}$

\section{Keterangan}

$\mathrm{SD}_{\mathrm{r}}=$ Standar deviasi keterulangan $(\mathrm{mg} / 100 \mathrm{~mL})$

$\mathrm{SD}_{\mathrm{R}}=$ Standar deviasi reprodusibilitas $(\mathrm{mg} / 100 \mathrm{~mL})$

$t_{95: 9}=$ Faktor $\mathrm{t}$ student untuk 9 derajat kebebasan dan tingkat kepercayaan 95\% (2.262)

\section{Prosedur Analisis Kalsium}

\section{Pembakuan larutan Na2EDTA}

Pembakuan larutan $\mathrm{Na}_{2}$ EDTA dilakukan dengan mentitrasi $220 \mathrm{mg} \mathrm{ZnSO}_{4}$. $7 \mathrm{H}_{2} \mathrm{O}$ yang telah ditambahkan $25 \mathrm{~mL}$ aquabides dan $5 \mathrm{~mL}$ buffer amonium klorida $\mathrm{pH}$ 10. Penambahan indikator Eriochrome Black T (EBT) $1 \%$ (b/b) sebanyak $50 \mathrm{mg}$ dilakukan pada saat titrasi dimulai. Titik akhir titrasi ditandai perubahan warna dari merah keunguan menjadi biru. Pembakuan larutan $\mathrm{Na}_{2}$ EDTA dilakukan sebanyak tiga kali ulangan. Penentuan molaritas dari Na2EDTA mengikuti Persamaan 4.

$$
\mathrm{M}=\frac{\mathrm{m}}{\mathrm{Mr}} \times \frac{1}{\mathrm{~V}}
$$

Keterangan:

$$
\begin{array}{ll}
\mathrm{M} & =\text { Molaritas } \mathrm{Na}_{2} \text { EDTA }(\mathrm{M}) \\
\mathrm{m} & =\text { Massa } \mathrm{ZnSO}_{4} \cdot 7 \mathrm{H}_{2} \mathrm{O}(\mathrm{mg}) \\
\mathrm{Mr} & =\text { Massa molekul relatif } \mathrm{ZnSO}_{4} \cdot 7 \mathrm{H}_{2} \mathrm{O} \\
\mathrm{V} & =\text { Volume } \mathrm{Na}_{2} \text { EDTA }(\mathrm{mL})
\end{array}
$$

\section{Titrasi sampel}

Sebanyak $4 \mathrm{~mL}$ sampel susu segar dipipet ke dalam erlenmeyer dan ditambahkan $100 \mathrm{~mL}$ aquabides. $\mathrm{pH}$ larutan yang akan dititrasi diatur hingga $\mathrm{pH}$ 12-13 dengan menambahkan $\mathrm{NaOH} 2 \mathrm{~N}$. Penambahan $50 \mathrm{mg}$ indikator mureksid $0,2 \%(\mathrm{~b} / \mathrm{b})$ dilakukan pada saat titrasi akan dimulai. Titrasi dilakukan dengan larutan $\mathrm{Na}_{2}$ EDTA 0,050 M yang sudah dibakukan. Titik akhir titrasi ditandai dengan perubahan warna dari merah muda menjadi ungu. Penentuan kadar kalsium pada susu segar mengikuti Persamaan 5.

Kadar kalsium $(\mathrm{mg} / 100 \mathrm{~mL})=\frac{\mathrm{M} \times \mathrm{V}_{1} \times 40,08 \times 100}{\mathrm{~V}_{2}}$

Keterangan

$\begin{array}{ll}\mathrm{M} & \left.=\text { Molaritas Na } \mathrm{NaDTA}_{2} \mathrm{M}\right) \\ \mathrm{V}_{1} & =\text { Volume Na } \\ \mathrm{V}_{2} & =\text { Volume sampel }(\mathrm{mL})\end{array}$

\section{HASIL DAN KESIMPULAN}

\section{Batas Deteksi dan Batas Kuantifikasi}

Batas deteksi (limit of detection) merupakan konsentrasi terkecil dari analit yang dapat dideteksi tetapi belum dapat dikuantifikasi secara benar (Kazusaki dkk., 2012), sedangkan batas kuantifikasi (limit of quantification) menurut Kantasubrata (2008), mer merupakan konsentrasi terendah dari analit yang dapat ditentukan dengan akurasi dan presisi yang baik. Pada penelitian ini, batas deteksi dan batas kuantifikasi ditentukan dengan menggunakan larutan standar kalsium pada konsentrasi rendah, yaitu $1 \mathrm{mg} / 100 \mathrm{~mL}$. Hasil pengujian batas deteksi dan batas kuantifikasi dapat dilihat pada Tabel 1. 
Tabel 1. Nilai batas deteksi dan batas kuantifikasi analisis kadar kalsium secara titrasi kompleksometri $(\mathrm{N}=7)$

\begin{tabular}{cc}
\hline Ulangan & $\begin{array}{c}\text { Konsentrasi kalsium } \\
(\mathrm{mg} / 100 \mathrm{~mL})\end{array}$ \\
\hline 1 & 1,15 \\
2 & 1,34 \\
3 & 1,34 \\
4 & 1,15 \\
5 & 0,96 \\
6 & 1,15 \\
7 & 0,96 \\
\hline Rata-rata & 1,15 \\
SD & 0,16 \\
Batas deteksi & 0,47 \\
Batas kuantifikasi & 1,57 \\
\hline
\end{tabular}

Nilai batas deteksi dan batas kuantifikasi yang diperoleh dari penelitian ini hampir sama dengan hasil penelitian Pratama dkk. (2015). Pratama dkk. (2015) melakukan validasi analisis beberapa logam pada air tua (bittern) dengan menggunakan instrumen Microwave Plasma-Atomic Emission Spectrometer (MP-AES). Nilai batas deteksi dan batas kuantifikasi yang diperoleh oleh Pratama dkk. (2015) berturut-turut adalah 0,5 mg/100 $\mathrm{mL}$ dan $1,7 \mathrm{mg} / 100 \mathrm{~mL}$.

\section{Linearitas}

Menurut Wenclawiak dan Hadjicostas (2010), linearitas (linearity) merupakan kemampuan untuk memberikan hasil yang proporsional terhadap konsentrasi analit pada rentang tertentu. Pada penelitian ini, linearitas ditentukan dengan menggunakan larutan standar kalsium pada beberapa konsentrasi, yaitu 4, 8, 12, 16, 20, dan 24 $\mathrm{mg} / 100 \mathrm{~mL}$. Hasil uji linearitas dapat dilihat pada Gambar 1.

Berdasarkan Gambar 1 terlihat nilai coefficient of determination $\left(\mathrm{R}^{2}\right)$ memenuhi nilai yang dipersyaratkan, yaitu lebih besar 0,99 (AOAC 2012). Hasil penelitian ini hampir sama dengan nilai $\mathrm{R}^{2}$ yang diperoleh Baldut dkk. (2015), yaitu 0,9995. Baldut dkk. (2015) melakukan validasi analisis kadar kalsium pada obat (rosuvastatin calcium) secara titrasi kompleksometri.

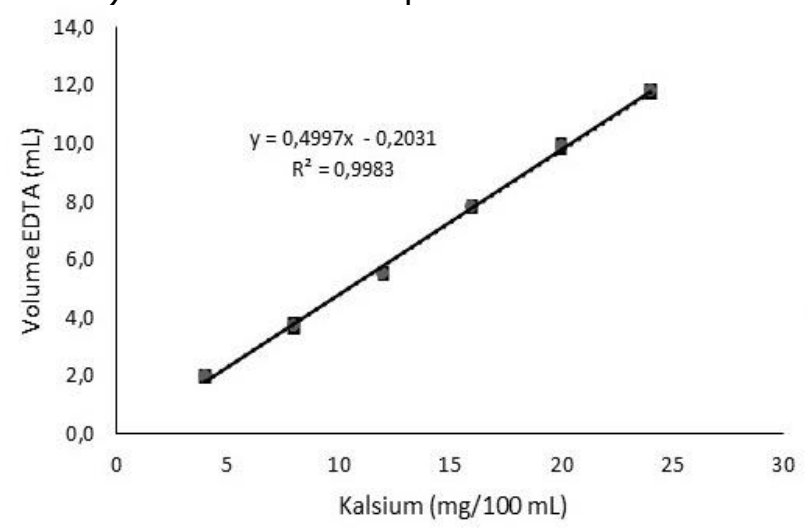

Gambar 1. Kurva linearitas dari analisis kadar kalsium secara titrasi kompleksometri $(\mathrm{N}=3)$

\section{Akurasi dan Keterulangan}

Akurasi (accuracy) menunjukkan kedekatan nilai hasil analisis terhadap nilai sebenarnya (Kazusaki dkk., 2012). Nilai akurasi dapat ditentukan dengan menggunakan metode spiking, yaitu menambahkan larutan standar kalsium pada sampel (susu segar). Konsentrasi spiking yang digunakan adalah $60 \mathrm{mg} / 100$ $\mathrm{mL}$ susu segar. Nilai recovery dari analisis kadar kalsium pada susu segar dapat dilihat pada Tabel 2.

Hasil pada Tabel 2 menunjukkan nilai recovery memenuhi nilai recovery yang dipersyaratkan oleh AOAC (2012), yaitu 90-108\%. Nilai recovery pada penelitian ini hampir sama dengan hasil penelitian Janagiraman dkk. (2014). Janagiraman dkk. (2014), melakukan validasi analisis kadar kalsium pada obat (Pitavastatin Calcium) secara titrasi kompleksometri. Hasil validasi Janagiraman dkk. (2014) menunjukkan nilai recovery sebesar 99,55\%.

Menurut Harmita (2004), keterulangan (repeatability) merupakan konsistensi hasil analisis jika dilakukan berulang kali oleh analis dan dalam interval waktu yang relatif pendek. Keterulangan pada penelitian ini ditentukan dengan menganalisis sampel beberapa kali ulangan. Keterulangan dapat diukur dari nilai CV

Tabel 2. Nilai akurasi dan keterulangan dari analisis kadar kalsium pada susu segar secaratitrasi kompleksometri $(\mathrm{N}=6)$

\begin{tabular}{|c|c|c|c|c|}
\hline Ulangan & $\begin{array}{c}\text { Kadar kalsium dari } \\
\text { sampel tanpa spike } \\
(\mathrm{mg} / 100 \mathrm{~mL})\end{array}$ & $\begin{array}{c}\text { Konsentrasi } \\
\text { spiking kalsium } \\
(\mathrm{mg} / 100 \mathrm{~mL}) \\
\end{array}$ & $\begin{array}{c}\text { Kadar kalsium dari } \\
\text { sampel yang di-spike } \\
(\mathrm{mg} / 100 \mathrm{~mL})\end{array}$ & Recovery (\%) \\
\hline 1 & \multirow{6}{*}{$142,10-147,00$} & 60 & 205,80 & 100,65 \\
\hline 2 & & 60 & 205,80 & 100,65 \\
\hline 3 & & 60 & 205,80 & 100,65 \\
\hline 4 & & 60 & 200,90 & 92,49 \\
\hline 5 & & 60 & 205,80 & 100,65 \\
\hline 6 & & 60 & 205,80 & 100,65 \\
\hline Rata-rata & & & 204,98 & 99,29 \\
\hline SD & & & 2,00 & 3,33 \\
\hline CV analisis (\%) & & & 0,98 & 3,36 \\
\hline
\end{tabular}


hasil analisis tersebut. Nilai CV analisis dapat dilihat pada Tabel 2. Berdasarkan Tabel 2 terlihat nilai CV analisis, yaitu 0,98\%, lebih kecil dari nilai CV keterulangan yang dipersyaratkan oleh AOAC (2012), yaitu maksimal 2\%. $\mathrm{Hal}$ ini menunjukkan tingkat keterulangan dari metode ini sangat baik.

\section{Reprodusibilitas Intralab}

Reprodusibilitas intralab

(intra-laboratory reproducibility) merupakan tingkat variasi hasil analisis sampel jika dilakukan pada waktu yang berbeda. Pada penelitian ini, analisis kadar kalsium pada susu segar dilakukan pada hari yang berbeda, selama tiga hari. Hasil uji reprodusibilitas intralab dapat dilihat pada Tabel 3.

Tabel 3. Hasil uji reprodusibilitas intralab dari analisis kadar kalsium pada susu segar secara titrasi kompleksometri

\begin{tabular}{cc}
\hline Hari ke- & Kadar kalsium sampel $(\mathrm{mg} / 100 \mathrm{~mL})$ \\
\hline 1 & $144,55 \pm 3.46$ \\
2 & $150,27 \pm 2,83$ \\
3 & $151,90 \pm 0,00$ \\
\hline Rata-rata & 149,18 \\
SD & 3,86 \\
CV analisis (\%) & 2,59 \\
\hline
\end{tabular}

Berdasarkan Tabel 3 terlihat nilai CV analisis lebih kecil dari nilai CV reprodusibilitas yang dipersyaratkan oleh AOAC (2012), yaitu maksimal 4\%. Hal ini menandakan bahwa reprodusibilitas intralab dari analisis kalsium pada susu segar secara titrasi kompleksometri dapat diterima pada tiga hari analisis.

\section{Ketangguhan Metode}

Ketangguhan (ruggedness) metode adalah kemampuan suatu metode analisis untuk tidak dipengaruhi oleh adanya variasi prosedur atau bahan kimia yang digunakan dalam analisis. Pada penelitian ini ketangguhan metode diuji dengan memvariasikan volume sampel yang digunakan, yaitu $3 \mathrm{~mL}, 4 \mathrm{~mL}$ dan $5 \mathrm{~mL}$, selain itu ketangguhan metode juga diuji dengan memvariasikan konsentrasi titran ( $\mathrm{Na}_{2} \mathrm{EDTA}$ ) yang digunakan, yaitu 0,025 M dan 0,050 M (Tabel 4).

Tabel 4. Hasil uji ketangguhan metode dari analisis kadar kalsium pada susu segar secara titrasi kompleksometri dengan variasi volume sampel dan konsentrasi $\mathrm{Na}_{2} \operatorname{EDTA}(\mathrm{N}=3)$

\begin{tabular}{ccc}
\hline \multicolumn{2}{c}{ Variasi perlakuan } & $\begin{array}{c}\text { Kadar kalsium sampel } \\
(\mathrm{mg} / 100 \mathrm{~mL})\end{array}$ \\
\hline Volume sampel & $3 \mathrm{~mL}$ & $150,27 \pm 0,00$ \\
& $4 \mathrm{~mL}$ & $150,27 \pm 2,83$ \\
& $5 \mathrm{~mL}$ & $146,35 \pm 2,26$ \\
\hline Konsentrasi & $0,025 \mathrm{M}$ & $151,90 \pm 0,00$ \\
$\mathrm{Na}_{2}$ EDTA & $0,050 \mathrm{M}$ & $151,67 \pm 1,44$ \\
\hline
\end{tabular}

Hasil uji statistik, yaitu One Way ANOVA untuk perlakuan variasi sampel dan uji t untuk perlakuan variasi konsentrasi $\mathrm{Na}_{2} \mathrm{EDTA}$ menunjukkan tidak terdapat perbedaan nyata kadar kalsium sampel antar perlakuan tersebut. Hal ini menunjukkan metode analisis kalsium pada susu segar bersifat tangguh terhadap variasi volume sampel dan konsentrasi $\mathrm{Na}_{2} \mathrm{EDTA}$ yang digunakan.

\section{Ketidakpastian}

Sumber ketidakpastian (uncertainty) dalam analisis kuantitatif dapat berasal dari sampel, sampling, gangguan, kondisi lingkungan dan peralatan (Riyanto, 2014). Pada penelitian ini, dua jenis ketidakpastian yang dianalisis adalah ketidakpastian keterulangan $\left(U_{r}\right)$ dan reprodusibilitas $\left(U_{R}\right)$ (Tabel 5$)$.

Tabel 5. Ketidakpastian keterulangan $\left(U_{r}\right)$ dan reprodusibilitas $\left(U_{R}\right)$ dari analisis kadar kalsium pada susu segar secara titrasi kompleksometri

\begin{tabular}{lcc}
\hline Parameter & $\begin{array}{c}\mathrm{SD}(\mathrm{mg} / 100 \\
\mathrm{mL})\end{array}$ & $\begin{array}{c}\text { Ketidakpastian } \\
(\mathrm{mg} / 100 \mathrm{~mL})\end{array}$ \\
\hline Keterulangan & 2,00 & 4,52 \\
Reprodusibilitas & 3,86 & 8.73 \\
\hline
\end{tabular}

\section{Perbandingan Kadar Kalsium}

Susu merupakan sumber mineral penting yang dibutuhkan oleh tubuh (Dandare dkk., 2014). Salah satu mineral tersebut adalah kalsium yang mempunyai kadar bervariasi berkisar antara 107-133 mg/100 g (Zamberlin dkk., 2012). Perbandingan kadar kalsium susu segar hasil penelitian ini dan hasil penelitian lain dengan menggunakan metode yang berbeda dapat dilihat pada Tabel 6.

Tabel 6. Perbandingan kadar kalsium pada susu segar dari hasil penelitian ini dan penelitian lain

\begin{tabular}{lcc}
\hline Sumber & $\begin{array}{c}\text { Kadar kalsium } \\
(\mathrm{mg} / 100 \mathrm{~mL})\end{array}$ & Metode penentuan \\
\hline $\begin{array}{l}\text { Penelitian ini } \\
\text { Budiman dkk. } \\
(2013)\end{array}$ & 144,55 & Titrasi kompleksometri \\
$\quad-$ Sampel A & 144,98 & $\begin{array}{c}\text { Atomic absorption } \\
\text { spectroscopy (AAS) } \\
\text { Atomic absorption } \\
\text { spectroscopy (AAS) }\end{array}$ \\
$\begin{array}{l}\text { - Sampel B } \\
\text { (2005) }\end{array}$ & 129,50 & \begin{tabular}{c} 
R \\
\hline
\end{tabular}
\end{tabular}

Kadar kalsium susu segar hasil penelitian ini hampir sama dengan kadar kalsium susu segar yang terdapat pada data komposisi bahan yang dikeluarkan oleh Depkes RI (2005), yaitu 143 mg/100 mL. Budiman dkk. (2013) juga menganalisis kadar kalsium pada dua sampel susu segar yang berasal dari peternakan berbeda. Hasil penelitian Budiman dkk. (2013) menunjukkan kadar kalsium sampel A mendekati kadar kalsium hasil penelitian ini, tetapi sampel B menunjukkan kadar kalsium yang berbeda. Menurut Looper (2012), ada beberapa faktor yang menyebabkan perbedaan komposisi antar susu segar, yaitu faktor genetik, usia dan lingkungan tempat sapi hidup. 


\section{KESIMPULAN}

Metode analisis kadar kalsium pada susu segar secara titrasi kompleksometri mempunyai nilai akurasi yang baik, yaitu $99,29 \%$ pada konsentrasi spiking $60 \mathrm{mg} / 100 \mathrm{~mL}$ sampel. Metode ini juga mempunyai nilai keterulangan dan reprodusibilitas intralab yang baik dengan nilai CV analisis berturut-turut $0,98 \%$ dan 2,59\%. Hasil uji ketangguhan menunjukkan metode bersifat tangguh (rugged) terhadap variasi volume sampel ( $3 \mathrm{~mL}$ sampai 5 $\mathrm{mL}$ ) dan konsentrasi $\mathrm{Na}_{2} \mathrm{EDTA}(0,025 \mathrm{M}$ sampai 0,050 M). Uji linearitas dengan menggunakan larutan standar kalsium pada rentang 4-24 mg/100 mL menghasilkan nilai coefficient of determination $\left(R^{2}\right)$ sebesar 0,9983, sedangkan nilai batas deteksi dan batas kuantifikasi berturut-turut adalah $0,47 \mathrm{mg} / 100 \mathrm{~mL}$ dan $1,57 \mathrm{mg} / 100$ $\mathrm{mL}$. Hasil-hasil tersebut menunjukkan bahwa metode titrasi kompleksometri dapat digunakan untuk menentukan kadar kalsium pada sampel susu segar.

\section{UCAPAN TERIMA KASIH}

Ucapan terima kasih kepada Direktorat Riset dan Pengabdian kepada Masyarakat, Direktorat Jenderal Penguatan Riset dan Pengembangan, Kementerian Riset, Teknologi dan Pendidikan Tinggi yang telah memberikan dukungan dana melalui hibah penelitian tahun anggaran 2017.

\section{DAFTAR PUSTAKA}

Al-Wabel, N. A. (2008). Mineral contents of milk of cattle, camels, goats and sheep in the central region of Saudi Arabia. Asian Journal of Biochemistry, 3(6), 373-375. http://doi.org/10.3923/ajb.2008.373.375

AOAC. (2012). Official Methods of Analysis of AOAC International (19 $9^{\text {th }}$ ed.). Maryland, MD: AOAC International Press

Baldut, M., Bonafede, S. L., Petrone, L., Simionato, L. D., \& Segall, A. I. (2015). Development and validation of a complexometric titration method for the determination of rosuvastatin calcium in raw material. Advances in Research, 5(5), 1-8. http://doi.org/10.9734/AIR/2015/19843

Barłowska, J., Szwajkowska, M., Litwińczuk, Z., \& Król, J. (2011). Nutritional value and technological suitability of milk from various animal species used for dairy production. Comprehensive reviews in food science and food safety, 10(6), 291-302. https://doi.org/10.1111/j.15414337.2011.00163.x

Basak, S., \& Kundu, D. (2013). Evaluation of measurement uncertainty components associated with the results of complexometric determination of calcium in ceramic raw materials using EDTA. Accreditation and Quality Assurance, 18(3), 235-241.

Beto, J. A. (2015). The role of calcium in human aging. Clinical nutrition research, 4(1), 1-8. https://doi.org/10.7762/cnr.2015.4.1.1

BSN. (2004). SNI 06-6989 13-2004. Air dan Air Limbah. Jakarta: Badan Standarisasi Nasional

Budiman, S., Nugroho, P., \& Fudiesta, Y. (2013). Studi penentuan kandungan kalsium dan kemungkinan terkontaminasinya logam timbal dalam susu sapi secara spektrofotometri serapan atom (SSA). Aristoteles, 10(2), 16-22.

Česnik, H. B., \& Gregorčič, A. (2006). Validation of the method for the determination of dithiocarbamates and thiuram disulphide on apple, lettuce, potato, strawberry and tomato matrix. Acta Chimica Slovenica, 53(1), 100-104.

Cai, J. B., Wang, S. F., Tang, P. P., \& Su, Q. D. (2009). Simultaneous determination of total nitrogen and metal elements in tobaccos by high performance ion chromatography. Journal of the Chinese Chemical Society, 56(4), 671-675. https://doi.org/10.1002/jccs.200900100

Dandare, S. U., Ezeonwumelu, I. J., \& Abubakar, M. G. (2014). Comparative analysis of nutrient composition of milk from different breeds of cows. Scholars Research Library European Journal of Applied Engineering and Scientific Research, 3(2), 33-36.

Day, R. A. \& Underwood, A. L. (2006). Analisis Kimia Kuantitatif (6 $6^{\text {th }}$ ed). Jakarta: Erlangga

Depkes RI. (2005). Daftar Komposisi Bahan Makanan. Jakarta: Departemen Kesehatan Republik Indonesia

Gobinathan, P., Murali, P. V., \& Panneerselvam, R. (2009). Interactive effects of calcium chloride on salinity-induced proline metabolism in Pennisetum typoidies. Advances in Biological Research, 3(5-6), 168-173.

Harmita, H. (2012). Petunjuk pelaksanaan validasi metode dan Cara Perhitungannya. Pharmaceutical Sciences and $\begin{array}{llll}\text { Research (PSR), 1(3), 117-135. } & \end{array}$ https://doi.org/10.7454/psr.v1i3.3375

Janagiraman, S., Raju, T., \& Giribabu, K. (2014). Simple Titrimetric Analysis for Determination of Pitavastatin Calcium in Bulk and Formulation Dosage. Int. J. Modern Chem, 6(1), 18-27.

Kantasubrata, J. (2008). Validasi Metode. Bandung: Pusat Penelitian LIPI

Kapadnis, K. H. (2015). Magnesium and calcium estimation from fresh milk samples in nashik region by a simple method. World Journal of Pharmacy And Pharmaceutical Sciences, 4(12), 793-797

Kazusaki, M., Ueda, S., Takeuchi, N., \& Ohgami, Y. (2012). Validation of analytical procedures by high- performance liquid chromatography for pharmaceutical analysis. Chromatography, 33(2), 65-73. https://doi.org/10.15583/jpchrom.2012.005

Kumaravel, S., \& Alagusundaram, K. (2014). Determination of mineral content in Indian spices by ICP-OES. Oriental journal of chemistry, 30(2), 631-636. http://dx.doi.org/10.13005/ojc/300231

Looper, M. (2012). Factors Affecting Milk Composition of Lactating Cows. Arkansas: University of Arkansas

Miefthawati, N. P., Gusrina, L., \& Axela, F. (2013). Penetapan kadar kalsium pada ikan kembung segar dan ikan kembung asin secara kompleksometri. Jurnal Analisis Kesehatan Klinikal Sains, 1(1), 1-9.

Nielsen, S. S. (2010). Complexometric Determination of Calcium. In Nielsen, S.S. (Ed.). Food analysis laboratory manual (pp. 61-67). New York, NY: Springer.

Park, Y. W., Juárez, M., Ramos, M., \& Haenlein, G. F. W. (2007). Physico-chemical characteristics of goat and sheep milk. Small ruminant research, 68(1), 88-113. https://doi.org/10.1016/j.smallrumres.2006.09.013

Petrovich, M. B., Filho, V. R. A., \& Neto, J. A. G. (2007). Direct determination of calcium in milk by atomic absorption spectrometry using flow-injection analysis. Eclética Química, 32(3), 25-30. http://dx.doi.org/10.1590/S0100- 
46702007000300004

Poirier, L., Nelson, J., Leong, D., Berhane, L., Hajdu, P., \& Lopez-Linares, F. (2016). Application of ICP-MS and ICP-OES on the determination of nickel, vanadium, iron, and calcium in petroleum crude oils via direct dilution. Energy \& Fuels, $30(5)$, 3783-3790. http://dx.doi.org/10.1021/acs.energyfuels.5b02997

Pratama, D. S., Pirdaus, P., Rinawati, R., Sagala, S. L., \& Suhelmi, I. S. R. (2015). Validasi metode analisis logam $\mathrm{Na}$, $\mathrm{K}, \mathrm{Mg}$ dan Ca pada air tua (bittern) menggunakan Microwave Plasma-Atomic Emission Spectrometer (MP-AES). Jurnal Standardisasi, 17(3), 187-198. http://dx.doi.org/10.31153/js.v17i3.318

Riyanto. (2014). Validasi dan Verifikasi Metode Uji. Yogyakarta: Deepublish Publisher

Rusdi, R., Maryesri, M., \& Zulharmitta, Z. (2013). Pembuatan Kalsium Karbonat Dari Batu Kapur Bukit Tui Kota Padang Panjang. Jurnal Farmasi Higea, 5(2), 159-166.

Setyawan, A. A., Mustofa, C. H., \& Hidayat, R. (2017). Pengaruh perebusan terhadap kadar kalsium pada bayam hijau (amaranthus tricolor, L) dengan metode kompleksometri. Motorik, 12(24), 75-83.

Sowmya, R., Indumathi, K. P., Arora, S., Sharma, V., \& Singh, A. K. (2015). Detection of calcium based neutralizers in milk and milk products by AAS. Journal of food science and technology, 52(2), 1188-1193.

Squadrone, S., Ferro, G. L., Marchis, D., Mauro, C., Palmegiano, P., Amato, G., ... \& Abete, M. C. (2010). Determination of melamine in feed: validation of a gas chromatography-mass spectrometry method according to 2004/882/CE regulation. Food Control, 21(5), 714-718. https://doi.org/10.1016/j.foodcont.2009.10.013

Ward, R. E., \& Carpenter, C. E. (2010) Traditional Methods for Mineral Analysis. In Nielsen, S. S. (Ed). Food analysis $4^{\text {th }}$ (pp. 201-2015). New York, NY: Springer

Wenclawiak, B., \& Hadjicostas, E. (2010). Validation of Analytical Methods-to be Fit for the Purpose. In Wenclawiak, Bernd W., Koch, M., \& Evsevios, H. (Eds.). Quality Assurance in Analytical Chemistry (pp. 215-245). Berlin Heidelberg: Springer

Zamberlin, Š., Antunac, N., Havranek, J., \& Samaržija, D. (2012). Mineral elements in milk and dairy products. Mljekarstvo/Dairy, 62(2), 111-125 